DOI: https://doi.org/10.24127/ajpm.v10i4.4337

\title{
PENGEMBANGAN LKPD BERBASIS PENDEKATAN RME PADA MATERI SEGIEMPAT UNTUK MENINGKATKAN KEMAMPUAN BERPIKIR KREATIF SISWA
}

\author{
Venty Emma Chahyanti ${ }^{1 *}$ Kamid $^{2}$, Evita Anggereini $^{3}$ \\ ${ }^{1,2}$ Program Magister Pendidikan Matematika FKIP UNJA, Jambi, Indonesia \\ ${ }^{3}$ Program Magister Pendidikan Biologi FKIP UNJA, Jambi, Indonesia \\ *Corresponding author. Jambi, 36361, Jambi, Indonesia. \\ E-mail: $\quad$ ventyemmac@gmail.com ${ }^{1 * 1}$ \\ kamid.fkip@unja.ac.id ${ }^{2)}$ \\ $\underline{\text { evita_pklh@yahoo.com }}^{3)}$
}

Received 18 October 2021; Received in revised form 17 November 2021; Accepted 27 December 2021

\begin{abstract}
Abstrak
Penelitian ini bertujuan untuk mengembangkan dan mengetahui kelayakan Lembar Kerja Peserta Didik (LKPD) berbasis pendekatan Realistic Mathematics Education (RME) pada materi segiempat untuk meningkatkan kemampuan berpikir kreatif siswa. Penelitian ini merupakan penelitian dan pengembangan yang menggunakan model ADDIE yang terdiri dari 5 tahap yaitu analisis (analysis), desain (design), pengembangan (development), pelaksanaan (implementation), dan evaluasi (evaluation). Subjek penelitian ini adalah siswa kelas VII SMP Swasta Islam Terpadu Trio Batanghari tahun ajaran 2021/2022. Dalam penelitian ini, dilakukan uji coba perorangan yaitu dengan satu orang guru, uji coba produk pada kelompok kecil yang terdiri dari 8 orang siswa dan uji coba kelompok besar terdiri dari 22 orang siswa. Instrumen yang digunakan dalam penelitian ini adalah angket validasi ahli dan angket uji coba perorangan, uji coba kelompok kecil dan uji coba kelompok besar serta tes kemampuan berpikir kreatif siswa. Analisis data penelitian ini dilakukan dengan menggunakan statistik deskriptif. Hasil penelitian ini yaitu sebuah LKPD berbasis pendekatan RME pada materi segiempat untuk meningkatkan kemampuan berpikir kreatif siswa, penilaian isi materi dan desain LKPD oleh ahli materi dan ahli desain LKPD, penilaian dan respon siswa terhadap LKPD yang telah dibuat, dan kemampuan berpikir kreatif siswa terhadap penggunaan LKPD berbasis pendekatan RME pada materi segiempat dengan memberikan post test.
\end{abstract}

Kata kunci: Kemampuan berpikir kreatif; LKPD; pendekatan RME.

\begin{abstract}
This study aims to develop and determine the feasibility of the Student Worksheet based on the Realistic Mathematics Education (RME) approach on rectangular material to improve students' creative thinking skills. This research is research and development that uses the ADDIE model which consists of 5 stages, namely analysis, design, development, implementation, and evaluation. The subjects of this study were 7 th grade students of the SMP Swasta Islam Terpadu Trio Batanghari in the 2021/2022 academic year. In this study, individual trials were conducted with one teacher, product trials in small groups consisting of 8 students and large group trials consisting of 22 students. The instruments used in this study were expert validation questionnaires and individual test questionnaires, small group trials and large group trials and tests of students' creative thinking skills. The data analysis of this research was conducted using descriptive statistics. The results of this study are an student worksheet based on the RME approach on rectangular material to improve students' creative thinking skills, assessment of material content and student worksheet design by material experts and student worksheet design experts, student assessments and responses to student worksheet that have been made, and students' creative thinking ability to use student worksheet based on the RME approach on rectangular material by providing a post test.
\end{abstract}

Keywords: Creative Thinking Skills, RME, Student Worksheet

This is an open access article under the Creative Commons Attribution 4.0 International License 


\section{PENDAHULUAN}

Menurut Kamid et al., (2018) matematika adalah pengetahuan logis tentang bentuk, susunan, skala, dan konsep yang diklasifikasikan ke dalam tiga bidang, seperti aljabar, analisis, dan geometri. Banyak yang memandang matematika sebagai mata pelajaran yang sulit yang tidak dapat banyak diterapkan dalam kehidupan sehari-hari.

Menurut Walle (2014) geometri harus dipelajari karena (1) geometri dapat mempermudah siswa memiliki keyakinan terhadap dunianya, (2) geometri dapat mempermudah siswa untuk menyelesaikan masalah, (3) gometri dapat mempermudah ilmu pengetahuan lainnya, (4) geometri dapat digunakan oleh banyak orang dalam kehidupan sehari-hari. Pada umumnya materi geometri lebih mudah dipahami siswa dibandingkan dengan cabang-cabang matematika lainnya, karena pada dasarnya banyak objek yang berhubungan dengan geometri sudah diketahui siswa dalam kehidupan sehari-hari (Patri, 2020).

Berdasarkan penelitian yang dilakukan Nasution (2019) menghasilkan LKPD berbasis penemuan dimana siswa lebih cenderung menghafal serta kurangnya pemahaman siswa dalam menyelesaikan suatu masalah yang diberikan oleh guru yang termuat di dalam LKPD tersebut dimana seharusnya siswa membutuhkan bahan ajar yang mampu membantu siswa dalam menyelesaikan masalah matematika.

Berdasarkan penelitian yang dilakukan oleh Barnes (2011) dijelaskan bahwa dengan menerapkan pendekatan RME ke dalam pembelajaran matematika siswa dapat memahami pembelajaran matematika dengan mudah. Berdasarkan penelitian yang dilakukan Sitorus (2016) dijelaskan bahwa dengan menerapkan suatu pendekatan Realistic Mathematics Education (RME) dapat menciptakan dan meningkatkan kemampuan berpikir kreatif siswa dalam menyelesaikan masalah matematika yang diberikan oleh guru yang termuat di dalam LKPD. Sehingga LKPD berbasis pendekatan RME ini adalah hal baru bagi siswa yang akan membuat siswa antusias untuk mengerjakan materi segiempat yang disajikan dalam LKPD yang dirancang dan dikembangkan oleh guru sehingga dapat meningkatkan kemampuan berpikir kreatif siswa.

Guru memiliki peranan penting dalam proses kegiatan belajar mengajar di dalam kelas. Pada kegiatan belajar mengajar sekarang, guru harus melibatkan siswa secara aktif dalam proses kegiatan belajar mengajar (Fionika et al., 2018). Salah satu cara yang dapat dilakukan guru untuk melibatkan siswa secara aktif dalam proses kegiatan belajar mengajar di kelas yaitu dengan menggunakan media atau bahan ajar menarik yang dapat mempermudah siswa dalam memahami konsep yang diajarkan oleh guru. Menurut Kamid et al., (2020) dengan adanya penyusunan bahan ajar, guru dapat mengembangkan kemampuan dalam mengolah dan menyesuaikan bahan ajar yang sesuai dengan karakteristik peserta didik dan memperoleh gambaran tentang cara membuat bahan ajar.

Agar pembelajaran dengan menggunakan LKPD dapat dipahami dan tidak abstrak karena materi geometri ini berkaitan langsung dengan dunia nyata maka dilakukan pembelajaran matematika yang berbasis realistic mathematics education (RME). Kelebihan RME 
menurut Hidayati (2013) yaitu memberikan pengertian yang jelas dan operasional kepada peserta didik tentang keterkaitan antara matematika dengan kehidupan sehari-hari (kehidupan dunia nyata) dan kegunaan matematika pada umumnya bagi manusia.

Menurut Mumford (2012) berpikir kreatif adalah kemampuan umum untuk menciptakan sesuatu yang baru, karena kemampuan untuk memberikan ide baru yang bisa diterapkan pada menyelesaikan masalah, atau sebagai kemampuan untuk mengetahui hubungan antara unsur yang sudah ada.

Dalam penelitian ini dikembangkan LKPD berbasis pendekatan RME. LKPD dikembangkan sebagai sumber pembelajaran matematika dan menciptakan kemampuan berpikir kreatif siswa dalam mencapai pemahaman terpadu atas informasi keilmuwan yang diperoleh, serta penerapan informasi keilmuwan tersebut dalam konteks pembelajaran yang kontekstual.

\section{METODE PENELITIAN}

Jenis penelitian ini berbentuk penelitian dan pengembangan (Researh and Development). Menurut Branch (2009) model pengem-bangan yang digunakan adalah pengembangan model ADDIE yang terdiri dari 5 tahap yaitu analisis (analysis), desain (design), (development), pengem-bangan pelaksanaan (implementation), dan evaluasi (evaluation).

Tahap analisis (analysis) merupakan tahap awal perencanaan, yaitu pemikiran tentang produk baru yang akan dikembangkan. Tujuan dari tahap analisis ini yaitu untuk mengidentifikasi kemungkinan penyebab kesenjangan yang terjadi. Pada tahap ini terdapat beberapa hal yang perlu diperhatikan dalam proses pengembangan yaitu analisis kurikulum, memvalidasi kesenjangan kinerja, menetapkan tujuan, analisis kebutuhan dan karakteristik siswa, analisis sumber daya yang tersedia, dan rencana kerja.

Tahap desain (design) perancangan ini bertujuan untuk memverifikasi kinerja yang diinginkan dan metode pengujian yang tepat. Pengembangan LKPD ini melalui beberapa tahap, yaitu: Rancangan LKPD berbasis Pendekatan RME, validasi desain (ahli materi, ahli desain pembelajaran, dan ahli media).

Tahap pengembangan (development) terdapat beberapa hal yang dikembangkan yaitu isi dari LKPD ini disesuaikan dengan materi dan tujuan pembelajaran yaitu uji coba perorangan, uji coba kelompok kecil, dan uji coba kelompok besar.

Tahap pelaksanaan (implementation) produk yang telah diujicoba diterapkan pada situasi nyata dengan pengajaran yang sesungguhnya. Pada penelitian ini tidak dilakukan tahap implementasi sebab tahap implementtasi adalah tahap dimana LKPD berbasis pendekatan RME yang telah dikembangkan diujikan pada seluruh peserta didik kelas VII dengan jumlah 22 siswa SMP Swasta Islam Terpadu Trio Batanghari dan pada seluruh materi yang dipelajari dikelas VII, sedangkan pada penelitian ini hanya dilakukan terhadap satu kelas dan satu materi pelajaran yakni segiempat.

Tahap evaluasi (evaluation) tujuan tahap evaluasi adalah menilai kualitas dari produk dan proses. Tahap evaluasi dilakukan beberapa tahap yaitu evaluasi yang dilakukan ahli 
media dan ahli materi melalui proses validasi produk, kemudian merevisi produk berdasarkan penilaian dan saran dari ahli desain pembelajaran dan media dan ahli materi serta hasil dari ujicoba produk dan validasi yang telah dilakukan dalam kelompok kecil sebanyak 8 orang siswa. Selanjutnya diujicobakan pada kelompok besar sebanyak 22 orang siswa.

Evaluasi dilakukan pada setiap tahap, evaluasi ini disebut evaluasi formatif. Sehingga diperoleh sebuah bahan ajar berupa LKPD yang layaknya untuk digunakan pada proses pembelajaran. Adapun evaluasi formatif berupa revisi yang didapat dari tim validator dan dari uji coba produk bahan ajar berupa LKPD. Selanjutnya evaluasi sumatif diperoleh dari penilaaian orang terhadap bahan ajar (LKPD) yang telah dibuat dengan angket persepsi peserta didik setelah menggunakan LKPD.

Subjek penelitian pada pengembangan ini adalah dua orang validator yang terdiri dari validator uji ahli materi dan validator uji ahli desain pembelajaran dan media. Sasaran pemakai dari produk ini adalah siswa kelas VII SMP.

Pada penilaian validasi ahli materi dilakukan oleh dosen program studi pendidikan matematika Universitas Jambi yang merupakan seorang yang ahli dan berpengalaman di bidang matematika sehingga penilaiannya terhadap media pembelajaran pada materi segiempat ini dapat membuat produk ini menjadi lebih baik. Untuk penilaian validasi ahli desain dan media dilakukan oleh dosen atau seorang ahli yang berpengalaman di bidang media pembelajaran, sehingga dapat membuat produk ini lebih baik.
Jenis data yang diambil dalam penelitian ini berupa data kualitatif dan data kuantitatif. Data kualitatif diperoleh dari hasil validator ahli materi dan ahli desain pembelajaran dan media, tanggapan dari guru bidang studi matematika, dan hasil angket tanggapan siswa terhadap media pembelajaran yang telah dibuat, sedangkan kuantitatif diperoleh dari hasil belajar siswa melalui post-test.

Analisis data penelitian ini dilakukan dengan menggunakan statistik deskriptif. Analisis meliputi analisis validasi instrumen penelitian dan LKPD, serta efektivitas LKPD. Analisis Validitas LKPD berbasis pendekatan RME divalidasi oleh tenaga ahli materi dan ahli desain. Validasi dilakukan untuk mengetahui kelebihan dan kelemahan dari produk yang akan dikembangkan, Setelah itu produk media pembelajaran di ujicobakan pada uji coba perorangan, kelompok kecil, dan kelompok besar. Pada uji coba perorangan, kelompok kecil dan kelompok besar diperoleh data dari angket terbuka yang berupa tanggapan guru dan siswa terhadap produk media pembelajaran yang dikembangkan, keseluruhan data yang didapat berupa data kualitatif.

Analisis efektivitas pembelajaran dilakukan terhadap hasil kompetensi belajar dan respon siswa. Kompetensi dalam penelitian ini adalah kemampuan berpikir kreatif siswa dan persepsi siswa terhadap LKPD. Kemampuan berpikir kreratif siswa disusun berdasarkan pedoman penilaian soal uraian yang sesuai dengan indikator kemampuan berpikir kreatif siswa. Untuk mengukur tingkat kemampuan berpikir kreatif siswa digunakan pretest dan post-test untuk melihat peningkatan pada kemampuan berpikir 
kreatif siswa dalam memanfaatkan produk LKD yang dikembangkan.

Kelayakan LKPD berbasis pende-katan RME dapat dilihat dari 3 aspek yaitu valid, praktis dan efektif. Dimana valid berdasarkan data yang diperoleh dari tim validator dapat disimpulkan bahwa LKPD berbasis pendekatan RME pada materi segiempat layak digunakan, praktis dengan tingkat kepraktisan dilihat dari pengamatan guru dengan memberikan pertimbangan bahwa materi mudah dan bisa digunakan oleh siswa dan guru itu sendiri. LKPD dikatakan praktis jika memenuhi indikator validator (guru atau ahlinya) dapat digunakan dengan sedikit atau tanpa revisi dan hasil analisis lembar pengamatan aktivitas siswa, dan keefektifan LKPD dilihat dari produk yang berkualitas tinggi yaitu dengan memenuhi indikator adanya respon positif siswa yang ditunjukkan melalui angket yang diberikan.

\section{HASIL DAN PEMBAHASAN}

Hasil dari penelitian pengembangan ini berupa (1) sebuah Lembar Kerja Siswa (LKPD) berbasis pendekatan Realistic Mathematics Education (RME) pada materi segiempat untuk meningkatkan kemampuan berpikir kreatif siswa, (2) penilaian isi materi dan desain LKPD oleh ahli materi dan ahli desain LKPD, (3) penilaian siswa terhadap LKPD yang telah dibuat, (4) Respon siswa terhadap penggunaan LKPD berbasis pendekatan RME pada materi segiempat yang didapat dari angket yang telah divalidasi oleh ahli instrumen, dan (5) kemampuan berpikir kreatif siswa terhadap penggunaan LKPD berbasis pendekatan RME pada materi segiempat dengan memberikan post-test kepada siswa kelas VII SMP IT Trio Batanghari. Penggunaan LKPD ini menggunakan model pengembangan ADDIE dengan langkah-langkah: (1) Analyze, (2) Design, (3) Development, Implementation, dan (5) Evaluation.

Pada tahap analyze dilakukan analisis kurikulum diperoleh bahwa kurikulum yang digunakan adalah Kurikulum 2013 untuk mengetahui seberapa kedalaman dan keluasan kurikulum yang digunakan di SMP Swasta Islam Terpadu Tio Batanghari. Selanjutnya dilakukan validasi kesenjangan kerja diperoleh bahwa penggunaan bahan ajar yang digunakan sekolah hanya berfokus pada buku paket. Selanjutnya menetapkan tujuan diperoleh bahwa dapat membantu para siswa untuk menguasai konten pembelajaran sekaligus meningkatkan kemampuan berpikir kreatif siswa. Selanjutnya analisis kebutuhan dan karekteristik siswa diperoleh bahwa siswa telah memiliki buku matematika sebagai referensi yang digunakan dalam pembelajaran matematika. Selanjutnya analisis sumber daya diperoleh bahwa sumber daya konten berupa buku matematika yang mengacu pada kurikulum 2013. Selanjutnya adapun rencana kerja yang telah dirancang yaitu pembentukan tim dan membuat spesifikasi LKPD serta struktur dan materi pokok pada LKPD. Pada tahap design yang dilakukan adalah membuat flowchart, storyboard, dan membuat LKPD berbasis pendekatan RME. Hasil validasi materi oleh Ibu Dr. Nizlel Huda, M.Kes terhadap LKPD berbasis pendekatan RME pada materi segiempat yang telah dibuat dengan mengisi angket yang terdiri dari 4 indikator dengan 13 pertanyaan. Hasil validasinya yaitu materi yang terdapat pada LKPD sesuai dengan tujuan pembelajaran materi segiempat, teknik 
penulisannya baik, penyusunan bahasanya baik dan disejutui untuk langsung digunakan dalam penelitian.

Hasil validasi desain pembelajaran oleh Ibu Dr. Nizlel Huda, M.Kes terhadap LKPD berbasis RME pada materi segiempat yang telah dibuat dengan mengisi angket yang terdiri dari 5 indikator dan 14 pertanyaan. Hasil validasinya yaitu desain pembelajaran yang terdapat pada LKPD sesuai dengan tujuan pembelajaran materi segiempat, teknik penulisannya baik, penyusunan bahasanya baik dan disejutui untuk langsung digunakan dalam penelitian.

Kemudian hasil validasi media oleh bapak Dr. Drs. Haryanto, M.Kes terhadap LKPD berbasis RME pada materi segiempat yang telah dibuat dengan mengisi angket yang terdiri dari 3 indikator dan 15 pertanyaan. Hasil validasinya yaitu bahan ajar LKPD nya sudah bagus dan layak diujicobakan langsung dalam penelitian. Serta dilakukan revisi desain pada tahap ini LKPD direvisi berdasarkan saran yang diberikan oleh validator materi, validator desain pembelajaran dan validator media. Saran yang diterima berupa saran dalam bentuk tulisan yang disampaikan maupun lisan yang disampaikan oleh ahli materi, ahli desain pembelajaran dan ahli media.

Pada tahap development setelah LKPD direvisi sesuai dengan saran dan komentar tim ahli, maka dilakukan evaluasi formatif untuk melihat efektifitas LKPD. Adapun tahapan dari evaluasi formatif terbagi atas 3 tahap yaitu uji coba perorangan (one-to-one trial), uji coba kelompok kecil (small group trial), dan uji coba kelompok besar (field tryout).

Uji coba perorangan dilakukan dengan subjek uji coba salah seorang guru matematika kelas VII yaitu Ibu
Suratmi, S.Pd yang akan menilai LKPD yang dibuat penulis secara keseluruhan sesuai dengan silabus dan kebutuhan siswa. Komentar dan saran dari uji coba praktisi adalah media pembelajaran yaitu LKPD yang didesain dengan menggunakan konteks dunia nyata didalamnya sangat membantu siswa dalam proses pembelajaran matematika dan dapat diujicobakan dilapangan. Karena siswa menemukan hal-hal baru yang belum ditemukan siswa pada LKPD sebelumnya. Dengan adanya LKPD berbasis RME ini siswa juga bisa lebih mengenal matematika dalam dunia nyata. Hasil yang diperoleh pada uji coba perorangan mendapatkan respon yang sangat positif sehingga dinyatakan layak untuk digunakan ketahap selanjutnya pada uji coba kelompok kecil.

Pada tahap uji coba kelompok kecil dilakukan terhadap non subjek uji coba penelitian. Siswa yang dipilih sebanyak 8 orang dari kelas VII SMPS IT Trio Batanghari dimana siswa ini berkemampuan rendah, sedang, dan tinggi. Pemilihan subjek uji coba kelompok kecil ini dibantu oleh guru matematika yang mengajar di kelas tersebut dan telah mengetahui kemampuan matematika siswa. Dalam uji coba kelompok kecil dilakukan dengan maksud memberikan masukan terhadap LKPD yang akan dikembangkan. Hasil evaluasi uji coba kelompok kecil tersebut digunakan untuk merevisi LKPD yang telah dibuat dengan mengarahkan siswa untuk mengamati keseluruhan LKPD, dan kemudian mengisi angket tanggapan yang telah diberikan. Pada uji coba kelompok kecil juga diadakan pre-test dan posttest. Pre-test dilakukan sebelum pembelaja-ran dilakukan menggunakan LKPD berbasis RME sedangkan post- 
DOI: https://doi.org/10.24127/ajpm.v10i4.4337

test diberikan setelah proses pembelajaran menggunakan LKPD selesai. Diperolah bahwa nilai siswa sebelum menggunakan LKPD semuanya kurang dari 55 sedangkan setelah menggunakan LKPD nilai siswa menjadi bervariasi dengan nilai mencapai 72. Skor gain didapat 0,7 berada pada kriteria tinggi untuk peningkatan kemampuan berpikir kreatif siswa.

Uji coba kelompok besar melibatkan 22 subjek (satu kelas), yaitu kelas VII SMPS IT Trio Batanghari. Kegiatan pembelajaran dilaksanakan dengan mengarahkan siswa untuk mengamati keseluruhan LKPD. Setelah pelaksanaan proses pembelajaran, masing-masing siswa diberikan angket untuk menilai aspek pada LKPD secara keseluruhan dan melihat tanggapan siswa terhadap penggunaan LKPD berbasis RME pada materi segiempat.

Sebelum siswa mengisi angket, diberikan penjelasan mengenai cara pengisian dan penjelasan mengenai isi masing-masing poin pada angket. Hasil rekapitulasi tanggapan siswa pada ujicoba kelompok besar adalah beranggapan sangat positif terhadap LKPD berbasis pendekatan RME yang digunakan. Karena tanggapan siswa pada uji coba kelompok besar ini positif, sehingga bisa menggunakan LKPD ini ke tahap selanjutnya pada tahap implementasi tanpa revisi.

Pada uji coba kelompok besar juga diadakan pre-test dan post-test. Pre-test dilakukan sebelum pembelajaran dilakukan menggunakan LKPD berbasis pendekatan RME sedangkan post-test diberikan setelah proses pembelajaran menggunakan LKPD selesai. Diperoleh bahwa nilai siswa sebelum menggunakan LKPD semuanya $<55$ sedangkan nilai siswa setelah menggunakan LKPD menjadi bervariasi dengan nilai mencapai 78 . Untuk uji gain melihat peningkatan kemampuan berpikir kretif siswa. Skor gain didapat 0,8 berada pada kriteria tinggi untuk peningkatan kemampuan berpikir kreatif siswa.

Pada tahap implementation produk yang telah diuji coba diterapkan dalam situasi nyata dengan pengajaran yang sesungguhnya menggunakan LKPD berbasis pendekatan RME pada materi segiempat yang melibatkan subjek 30 siswa atau satu kelas yaitu kelas VII SMPS IT trio Batanghari. Kegiatan pembelajaran dilaksanakan selama 3 kali pertemuan. Sebelum melaksanakan pembelajaran harus mempersiapkan RPP terlebih dahulu. Pada kegiatan pendahuluan yang dilakukan adalah doa dan salam serta melakukan apersepsi tujuan pembelajaran yang akan dicapai, kaitan dengan pelajaran lain, dan menjelaskan bahan ajar yang digunakan sebagai kegiatan pembelajaran serta siswa dibagi dalam beberapa kelompok. Dalam satu kelompok terdiri dari 5-6 orang siswa.

Sebelum memulai proses pembelajaran dan membagi kelompok, dilakukan pre-test untuk mengetahui kemampuan berpikir kreatif siswa sebelum menggunakan LKPD. Selanjutnya diberikan penjelasan proses pembelajaran dan petunjuk penggunaan LKPD berbasis pendekatan RME.

Pembelajaran dimulai dengan materi jenis-jenis segiempat siswa akan dibimbing mempelajari jenis-jenis segiempat terlebih dahulu sesuai dengan rencana pelaksanaan pembelajaran. Siswa diberikan LKPD berbasis pendekatan RME dan siswa sangat antusias untuk melihat gambar yang terdapat di LKPD. Selain gambar beserta penjelasannya diberikan juga beberapa pertanyaan dan permasalahan 
yang harus mereka selesaikan. Dari permasalahan yang diberikan di dalam LKPD, siswa diminta menjawab dengan benar dan diminta pendapatnya tentang masalah tersebut yang merupakan langkah dari proses dalam pembelajaran, kegiatan ini bertujuan agar siswa mampu mengelompokkan jenis-jenis segiempat dengan berbagai ukuran dengan cara mengamati, mencoba merangkai dan menggambarkan kembali segiempat yang telah dibuat serta menanamkan konsep dan skema materi segiempat.

Setelah mengetahui konsep materi berupa objek yang dipelajari siswa diminta agar dapat mengidentifikasi sifat-sifat segiempat terutama persegi panjang dan persegi dan mengaitkan konsep pembelajaran tersebut dengan materi yang akan dipelajari selanjutnya. Siswa juga dituntut agar dapat menyelesaikan setiap permasalahan yang ada pada LKPD.

Kegiatan akhir melakukan refleksi dengan melakukan Tanya jawab untuk memperkuat skema yang didapat dan menyampaikan apa saja yang mereka dapatkan dan mampu mereka kuasai selama proses pembelajaran pada materi segiempat. Terakhir kegiatan penutup yaitu meminta siswa mengerjakan post-test serta memberikan angket persepsi siswa pada siswa.

Angket yang digunakan merupakan angket tertutup dan digunakan untuk menilai aspek pada LKPD secara keseluruhan. Rata-rata setiap pertanyaan angket memiliki skor persentase lebih dari $80 \%$ dan dinyatakan sangat baik, untuk skor persentase keseluruhan yaitu 95\% yang artinya persepsi siswa sangat baik terhadap LKPD. Dari data tersebut dapat disimpulkan bahwa LKPD berbasis
RME dipersepsikan sangat baik oleh siswa.

Pada tahapan implementasi juga dilakukan pre-test dan post-test bertujuan untuk melihat peningkatan kemampuan berpikir kreatif siswa. Diperoleh bahwa rata-rata nilai siswa sebelum menggunakan LKPD kurang dari 70 sedangkan setelah menggunakan LKPD menjadi bervariasi dengan nilai mencapai 86. Untuk uji gain (melihat peningkatan kemampuan berpikir kreatif siswa), terlihat skor gain didapat 0,7 berada pada kriteria tinggi.

Evaluasi yang dimaksudkan untuk memperbaiki LKPD di setiap tahapnya, evaluasi ini disebut evaluasi formatif. Sehingga diperoleh sebuah LKPD yang layak untuk digunakan pada proses pembelajaran. Adapun evaluasi yang secara umum adalah melihat persepsi, pengetahuan dan sikap, evaluasi ini juga disebut evaluasi sumatif. Namun pada penelitian ini hanya sampai melihat pengetahuan. Dari evaluasi ini akan diperoleh hasil berupa LKPD yang dikatakan efektif bila media dipersepsikan secara positif oleh siswa dan tujuan dari pengembangan LKPD ini tercapai yaitu meningkatnya kemampuan berpikir kreatif siswa untuk materi segiempat.

Berdasarkan evaluasi yang dilakukan didapat LKPD berbasis pendekatan RME yang valid menurut tim ahli validator, ditanggapi dengan tanggapan positif oleh guru mata pelajaran matematika SMPS IT Trio Batanghari, dinilai dengan tanggapan yang positif oleh siswa pada ujicoba produk LKPD sehingga LKPD tidak mengalami revisi untuk tahapan implementasi. Pada tahapan implementasi didapat hasil persepsi siswa sangat baik terhadap LKPD yang dikembangkan, dan hasil kemampuan 
DOI: https://doi.org/10.24127/ajpm.v10i4.4337

berpikir kreatif siswa mengalami peningkatan dari yang tidak berpikir kreatif menjadi cukup berpikir kreatif sampai dengan sangat berpikir kreatif. Berdasarkan hasil yang didapat, dapat disimpulkan bahwa LKPD berbasis pendekatan RME efektif terhadap pembelajaran pada materi segiempat.

Produk LKPD berbasis pendekatan RME pada halaman sampul, halaman kegiatan belajar1, kegiatan belajar2, dan kegiatan belajar 3 dapat dilihat pada Gambar 1 sampai Gambar 4.

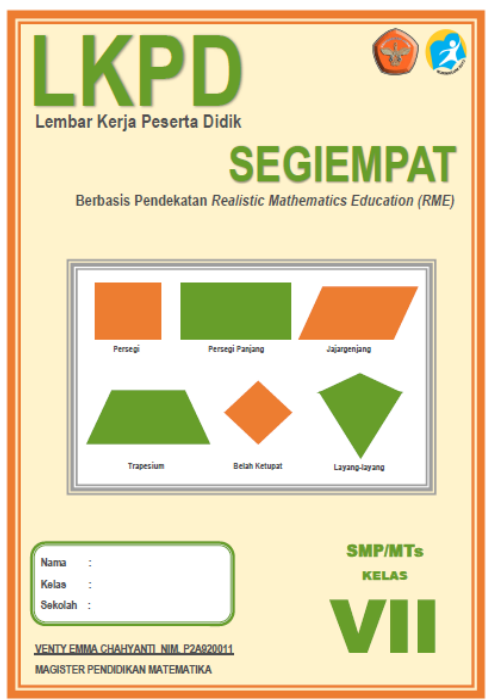

Gambar 1. Halaman sampul

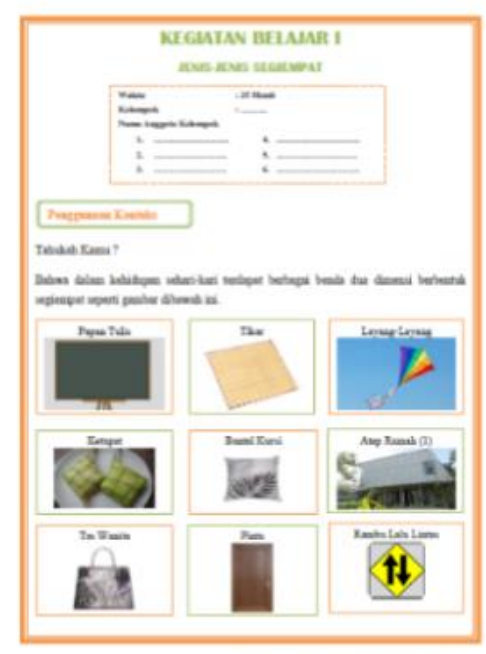

Gambar 2. Halaman kegiatan belajar 1

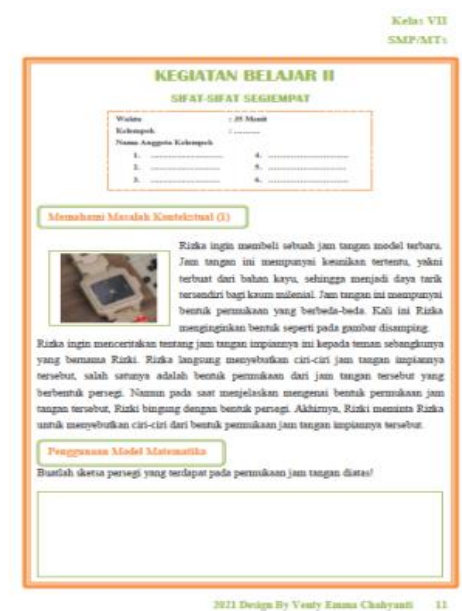

Gambar 3 Halaman kegiatan belajar 2

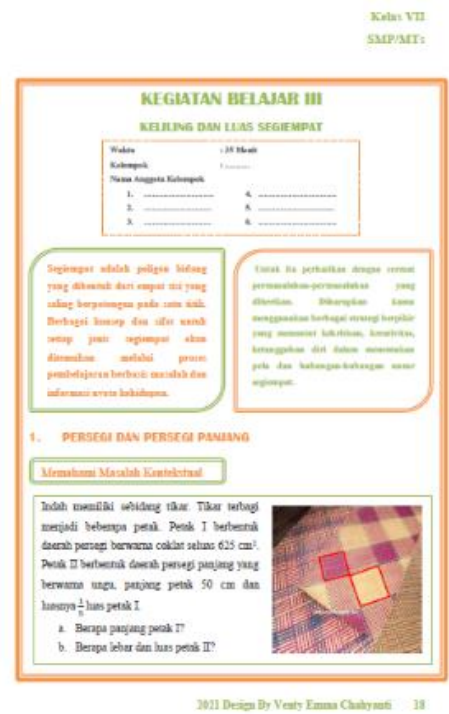

Gambar 4 Halaman kegiatan belajar 2

Hasil penelitian ini sejalan dengan penelitian yang dilakukan oleh Nasution (2019) dalam penelitian tersebut menghasilkan LKPD berbasis penemuan dimana siswa dalam menyelesaikan masalah yang disajikan dalam LKPD dengan baik dan sesuai tahap. Selain itu, pada penelitian yang dilakukan Barnes (2011) dalam penelitian tersebut dijelaskan bahwa dengan menerapkan pendekatan RME kedalam LKPD siswa dapat memahami pembelajaran matematika dengan mudah serta dapat memberikan dan menciptakan pembelajaran bermakna untuk mencapai pemahaman terpadu 
atas informasi keilmuwan yang diperoleh, serta penerapan informasi keilmuwan tersebut dalam konteks pembelajaran yang kontekstual.

Penelitian ini juga sejalan dengan penelitian yang dilakukan Sitorus (2016) dengan judul "Students creative thinking process stages: Implementation of realistic mathematics education" dalam penelitian tersebut dijelaskan bahwa dengan menerapkan suatu pendekatan RME dapat menciptakan dan meningkatkan kemampuan berpikir kreatif siswa dalam menyelesaikan masalah matematika yang diberikan oleh guru di dalam LKPD.

Selain itu penelitian yang dilakukan oleh Juwita et al. (2019) diperoleh bahwa skor rata-rata perolehan hasil tes kemampuan berfikir kreatif siswa menunjukkan bahwa total rata-rata skor $\mathrm{N}$-Gain adalah 0,75 dengan kategori tinggi. Tingginya keterampilan berfikir kreatif siswa yang telah dicapai pada setiap aspek keterampilan berfikir kreatif berdasarkan soal yang diberikan serta keefektifan bahan ajar yang dikembangkan memenuhi kategori efektif melihat respon positif peserta didik dengan. lebih dari $85 \%$ yang dikategorikan tinggi.

Hal ini juga sesuai dengan penelitian yang oleh Sutrimo et al. (2019) diperoleh bahwa menggunakan LKPD berbasis model Inquiry memberikan kemampuan berpikir kreatif yang lebih tinggi dibandingkan dengan pembelajaran yang tidak menggunakan LKPD berbasis model Inquiry pada materi pokok bangun ruang sisi lengkung kelas IX SMP serta hasil penelitian terhadap LKPD yang dikembangkan, dapat disimpulkan tes hasil belajar yang dilakukan pada akhir penelitian, LKPD yang dikembangkan dinyatakan efektif. Hal ini ditunjukkan oleh persentase ketuntasan klasikal siswa sebesar 84,62\% sehingga ketuntasan klasikal siswa pada klasifikasi baik.

Adapun kontribusi penelitian ini terhadap ilmu pengetahuan dan teknologi yaitu dapat digunakan sebagai sumber belajar bagi guru maupun siswa dalam kegiatan belajar mengajar serta dapat dijadikan referensi mahasiswa dalam menyelesaikan tugas akhir.

\section{KESIMPULAN DAN SARAN}

Berdasarkan hasil penelitian dan pembahasan dapat disimpulkan bahwa hasil pengembangan LKPD berbasis pendekatan RME pada materi segiempat dengan menggunakan model pengembangan ADDIE dapat meningkatkan kemampuan berpikir kreatif siswa dan kelayakan LKPD berbasis pendekatan RME pada materi segiempat untuk meningkatkan kemampuan berpikir kreatif siswa yaitu valid, praktis dan efektif.

Berdasarkan penelitian diatas diharapkan pada penelitian pengembangan selanjutnya agar dapat mengembangkan LKPD matematika lainnya dengan variasi-variasi lain untuk menghasilkan LKPD matematika yang lebih baik dan menarik. Serta menyarankan kepada guru pelajaran matematika untuk menggunakan LKPD berbasis pendekatan RME pada materi segiempat ini secara langsung ataupun sebagai referensi belajar siswa, karena akan membuat siswa lebih termotivasi dan tertarik dalam mempelajari matematika, serta mempermudah guru dalam menyampaikan materi.

\section{DAFTAR PUSTAKA}

Barnes, H. (2011). Realistic mathematics education: Eliciting alternative mathematical conceptions of learners. African Journal of Research in Mathematics, Science and Technology Education, 8(1), 
DOI: https://doi.org/10.24127/ajpm.v10i4.4337

53-64.

https://doi.org/10.1080/10288457. 2004.10740560

Branch, R. (2009). Instructional Design The ADDIE Approach. USA: Springer.

Fionika, B. Y. O., Kamid, K., \& Anggereini, E. (2018). The Influence of the SAVI Approach and Learning Styles on Student's Creative Math Skills. Mathematics Education Journal, 2(2), 106. https://doi.org/10.22219/mej.v2i2. 6495

Hidayati, K. (2013). Pendekatan Pendidikan Matematika Realistik Indonesia di SD Negeri 179 Palembang. Jurnal Cendekia, 11(1), 163-181.

Juwita, R., Putri Utami, A., \& Sri Wijayanti, P. (2019). Pengembangan LKS Berbasis Pendekatan Open-Ended untuk Meningkatakan kemampuan berpikir Kreatif Matematis Siswa. Jurnal Pendidikan Matematika, 3(1), 35-43.

Kamid, Wandari, A., \& Rohati. (2018). Ethnomathematics analysis on Jambi plait art as the mathematics learning resources. Journal of Physics: Conference Series, 1088. https://doi.org/10.1088/17426596/1088/1/012055

Kamid, K., Yuliya, S., \& Muhaimin, M. (2020). Pengembangan Modul Panduan Guru Matematika Dalam Mendesain Pembelajaran PJBL Berbasis Budaya Jambi. AKSIOMA: Jurnal Program Studi Pendidikan Matematika, 9(2), 424. https://doi.org/10.24127/ajpm.v9i2 .2796

Mumford, M. (2012). Creative thinking: Processes, strategies, and knowledge. Journal of Creative Behavior, 46(1), 30-47. https://doi.org/10.1002/jocb.003

Nasution, D. (2019). Development of student worksheets based on discovery learning to improve student mathematical problem solving ability in class $\mathrm{X}$ senior high school. International Journal of Scientific and Technology Research,8(6),228-231.

Patri, S. F. D. (2020). Ethnomathematical Analysis of Geometry Form in the Great Mosque of Pondok Tinggi at Sungai Penuh City and Relationship to Mathematics Instructional. International Journal of Social Sciences \& Educational Studies, 3(5), 15-22.

Sitorus, J. (2016). Students' creative thinking process stages: Implementation of realistic mathematics education. Thinking Skills and Creativity. 22, 111-120. https://doi.org/10.1016/j.tsc.2016.0 9.007

Sutrimo, S., Kamid, K., \& Saharudin, S. (2019). LKPD Bermuatan Inquiry dan Budaya Jambi: Efektivitas dalam Meningkatkan Kemampuan Berpikir Kreatif Matematis. IndoMath: Indonesia Mathematics Education, 2(1), 29. https://doi.org/10.30738/indomath.v 2i1.3841

Walle, J. V. D (2014). Geometric thinking and geometric concepts. Elementary and Middle School Mathematics: Teaching Developmentally., 4th, 306-312. 